\title{
Penerapan Algoritma SAGE pada Pengukuran Kanal Indoor Menggunakan SDR-USRP
}

\author{
Musayyanah*1 \\ ${ }^{1}$ Institut Bisnis dan Informatika Stikom Surabaya; Raya Kedung Baruk No.98, \\ 8721731/8710218. \\ e-mail: *1'musayyanah@stikom.edu
}

\begin{abstract}
Cooperative Wireless Communications forming MIMO array of virtual communication systems, which can improve the speed of data transmission, the speed is affected by channel conditions, that required the technique of channel analysis. The channel can be identified by knowing the characteristics of the physical parameters of the channel, like delay, angle, and amplitude complex. Detection of the physical parameters, from measurement of indoor or outdoor channel should use some methods with high accuracy, such as Space Alternate Generalized Expectation Maximization (SAGE). In this paper, we discuss the application of SAGE, to detect the angle parameters consists of Direction of Arrival (DoA) and the Direction of Departure (DoD), uses a communication device, Software Define Radio (SDR) such as Universal Software Radio Peripheral (USRP) that can detect three signals from measuring the indoor channel. The results of SAGE are compared with the results of Ray Tracing, where the average error for DoD detection was $36.3 \%$ while the DoA approximately $29.3 \%$
\end{abstract}

Keywords-SAGE, SDR, USRP, DoA, DoD, Koperatif, MIMO,Ray Tracing

\begin{abstract}
Abstrak
Komunikasi Koperatif Nirkabel membentuk system komunikasi virtual array MIMO, yang dapat meningkatkan kecepatan pentransmisian data, kecepatan tersebut dipengaruhi oleh kondisikanal, oleh sebab itu dibutuhkan analisis kondisi kanal. Kondisi suatu kanal dapat diindentifikasi dengan mengetahui karakteristik parameter fisikkanal, yaitu delay, sudut, dan amplitude kompleks. Deteksi parameter fisik kanal dari pengukuran kanal indoor maupun outdoor menggunakan metode dengan tingkat akurasi tinggi, seperti Space Alternating Generalized EM (SAGE). Penelitian ini mengimplementasikan SAGE untuk mendeteksi parameter sudut yang terdiri dari Direction of Arrival (DoA) dan Direction of Departure (DoD) menggunakan perangkat komunikasi Software Define Radio (SDR), yaitu Universal Software Radio Peripheral (USRP) yang dapat mendeteksitiga sinyal dari pengukuran kanal indoor. Hasil SAGE divalidasi terhadap hasil Ray Tracing, dimana rata-rata kesalahan untuk deteksi DoD adalah $36.3 \%$ sedangkan DoA sekitar $29.3 \%$.
\end{abstract}

Kata kunci-SAGE, SDR, USRP, DoA, DoD, Koperatif, MIMO,Ray Tracing

\section{PENDAHULUAN}

Proses komunikasi nirkabel yang menggunakan antena omnidireksional sebagai antena tunggal, memanfaatkan antena pengguna lain sebagai mitra, yang dikenal dengan Komunikasi Koperatif. Komunikasi Koperatif membentuk virtual array pada pemancar dan penerima, sehingga meskipun menggunakan satu antena, pengguna dapat melakukan komunikasi dengan laju data tinggi seperti sistem komunikasi pada Multiple Input Multiple Output (MIMO).

Pemodelan kanal koperatif MIMO telah dilakukan oleh [1]. Analisis kanal koperatif MIMO berkaitan dengan karakteristik kondisi kanal. Kondisi kanal tersebut dapat digambarkan 
dari parameter fisik kanal seperti delay, sudut yang terdiri dari Direction of Arrival (DoA) dan Direction of Departure (DoD), serta amplitudo kompleks.

Parameter kanal fisik didapatkan dari pengukuran kanal secara [2], yang menggunakan Virtual Network Analyzer (VNA) dan bentuk geometri antena array berbentuk kubus, proses pengolahan datanya dalam domain frekuensi. Pengukuran sintetik ini dianggap memiliki keterbatasan yaitu hanya bisa dilakukan pada lingkungan statis sehingga membutuhkan waktu yang lama. Selain itu, dibutuhkan suatu metode untuk mendapatkan parameter kanal fisik tersebut.

Salah satu metode yang digunakan untuk mendapatkan parameter fisik kanal adalah metode Deterministic Parametric Estimation (DPE) [3]. Contoh dari DPE adalah Expectation Maximization (EM), namun EM terlalu kompleks sehingga membutuhkan proses komputasi yang besar dan tingkat akurasi dalam estimasi parameter rendah. Kelemahan tersebut diperbaiki dengan muncul metode baru yaitu Space Alternating Generalized EM (SAGE).

SAGE telah dibuktikan mempunyai kelebihan dibandingkan dengan metode lain, salah satunya adalah SAGE dapat diterapkan pada sebarang bentuk geometri antena dan dapat mendeteksi sinyal dari kanal multipath. SAGE merupakan metode yang mempunyai tingkat konvergensi tinggi untuk mendapatkan parameter fisik kanal [4]. Selain itu SAGE telah dibuktikan mempunyai kinerja yang baik dalam mengestimasi parameter kanal secara berurutan tanpa memperhatikan urutan dari parameter tersebut [5].

Selain pengujian kinerja dari metode SAGE yang dilakukan secara simulasi, dapat pula dilakukan dengan pengukuran kanal secara real time, seperti yang tersampaikan pada makalah ini atau yang disebut pengukuran dalam domain waktu. Pengukuran kanal indoor maupun outdoor, yang menggunakan perangkat Software Define Radio (SDR) yaitu Wireless Open Access Reseacrh Platform (WARP), dimana pengolahan datanya dalam domain waktu. WARP memiliki keterbatasan jika digunakan sebagai analisis kondisi kanal, hal ini dikarenakan resolusi temporal alat tersebut besar yaitu $400 \mathrm{~ns}$, Hal ini menyebabkan sinyal yang berdekatan tidak terdeteksi dengan baik [6]. Untuk mengatasi hal tersebut, maka pada makalah ini, menggunakan perangkat Universal Software Radio Peripheral (USRP), dimana perangkat ini mempunyai resolusi temporal yang lebih baik yaitu sekitar 60ns.

Penelitian inimembahas penerapan SAGE dalam mendeteksi parameter kanal indoor Hall Gedung Baru-Politeknik Elektronika Negeri Surabaya. Hasil penerapan tersebut divalidasi oleh Ray Tracing. Ray Tracing merupakan suatu teori yang mendefinisikan posisi pemancar, penerima dan semua kemungkinan lintasan yang diperhitungkan secara geometris sesuai ukuran lokasi pengukuran [7].

\section{METODE PENELITIAN}

Tahapan untuk mendapatkan parameter fisik kanal dari hasil pengukuran ditunjukkan pada Gambar 1.

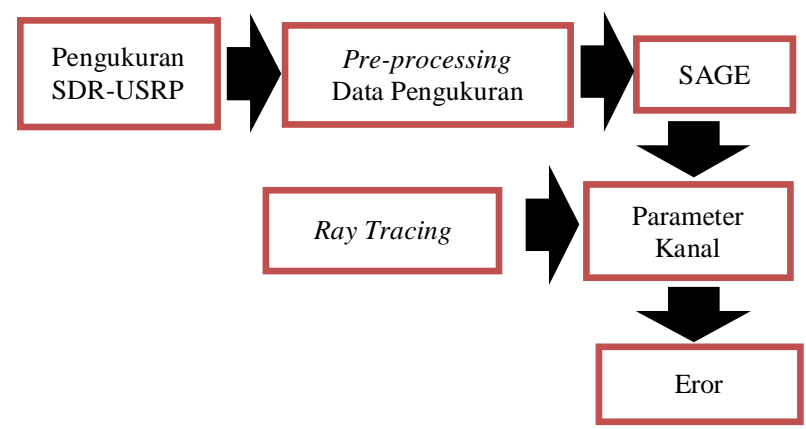

Gambar 1. Tahap untuk Mendapatkan Parameter Fisik 
Berdasarkan blok diagram alur penelitian, berikut penjelasan tentang setiap komponen dari blok tersebut.

\subsection{SDR (Software Define Radio) - USRP (Universal Software Radio Peripheral)}

Salah satu perangkat keras pengolahan sinyal digital disebut Software Define Radio (SDR). SDR merupakan perangkat komunikasi nirkabel yang dapat deprogram ulang dengan mode dan pita frekuensi yang diatur pada perangkat lunak [8]. Salah satu perangkat SDR yang digunakan pada makalah ini adalah Universal Software Radio Peripheral (USRP). USRP didukung oleh beberapa perangkat lunak sebagai antarmuka. Perangkat lunak tersebut adalah LabVIEW, Matlab/Simulink, dan GNU Radio.

USRP terdiri dari motherboard dan daughterboard. Motherboard dari USRP merupakan FPGA yang bekerja di rentang frekuensi $0 \mathrm{~Hz}-6 \mathrm{GHz}$. Motherboard ini berfungsi sebagai Digital Up Converter (DUC) dan Digital Down Converter (DDC), selain itu motherboard ini juga dapat mengubah sinyal analog ke digital (ADC) maupun mengubah sinyal digital keanalog (DAC). Sedangkan daughterboard dari USRP sebagai RF front end yang digunakan untuk menentukan rentang frekuensi kerja radio, sebagai filter, mixer dan amplifier. Seri USRP yang digunakan pada penelitian ini adalah NI-2922 yang merupakan produk dari Ettus Research, yang ditunjukkan pada Gambar 2.

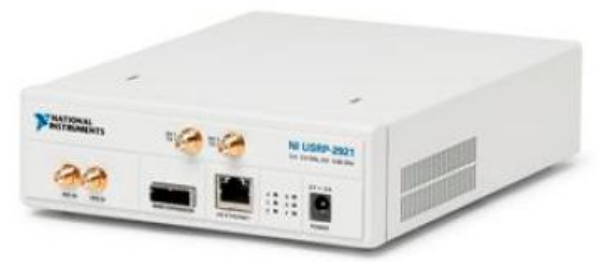

Gambar 2. Perangkat USRP Ni-2922

Siklus pengiriman pada USRP melewati beberapa proses yang dimulai dari penyamplingan pada sinyal baseband IF yang dilakukan oleh ADC, kemudian FPGA mengatur clock rate untuk proses penyamplingan tersebut, kemudian dilanjutkan dengan proses decimasi oleh beberapa filter. Setelah desimasi data dikirimkan ke host PC penerima. Blok diagram dari USRP ditunjukkan pada Gambar 3.

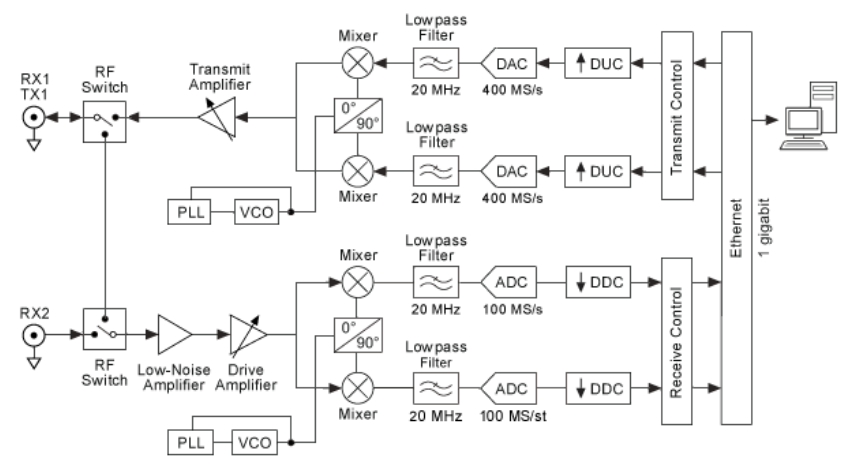

Gambar 3. Blok Diagram USRP NI-2922 [9]

Spesifikasi dari USRP NI2922 disajikan pada Tabel 1. 
Tabel 1. Spesifikasi USRP NI2922

\begin{tabular}{|l|l|}
\hline \multicolumn{1}{|c|}{ Parameter } & \multicolumn{1}{c|}{ Value } \\
\hline Range frekuensi & $400 \mathrm{MHz}-4.4 \mathrm{GHz}$ \\
\hline Switch adj TX frekuensi step & $1 \mathrm{KHz}$ \\
\hline Max power output & $15 \mathrm{dBm}-20 \mathrm{dBm}$ \\
\hline Gain power output TX & $0 \mathrm{~dB}-31,5 \mathrm{~dB}$ \\
\hline Switch adj power output step & $1 \mathrm{~dB}$ \\
\hline $\begin{array}{l}\text { Instantaneous Real Time } \\
\text { Bandwidth }\end{array}$ & $20 \mathrm{MHz}(16$ bit samples $)$ \\
\cline { 2 - 2 } & $40 \mathrm{MHz}(8$ bit samples) \\
\hline DAC & 2 channel, $400 \mathrm{MS} / \mathrm{s}, 16$ bit \\
\hline ADC & 2 channel, $100 \mathrm{MS} / \mathrm{s}, 14$ bit \\
\hline Max power input & $0 \mathrm{dBm}$ \\
\hline Noise Figure & $5-7 \mathrm{~dB}$ \\
\hline
\end{tabular}

Sebelum melakukan pengukuran kanal pada frekuensi $2.4 \mathrm{GHz}$, maka langkah pertama adalah mengetahui daya pancar dari USRP NI-2922. Daya pancar USRP NI-2922 menurun pada frekuensi kerja yang semakin tinggi, seperti pada Gambar 4.

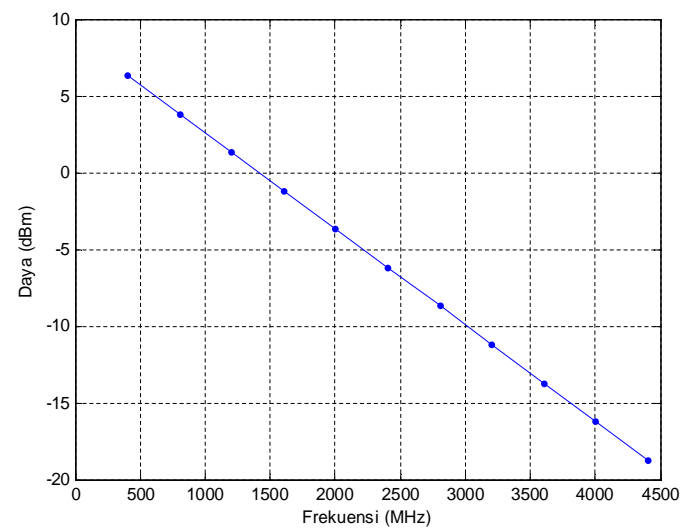

Gambar 4. Regresi Linear Daya Pancar USRP NI2922 (Gain 0 dB) [10].

\subsection{Pre-Processing Data Pengukuran}

Sistem Pengukuran dalam domain waktu menggunakan kode Pseudo Noise (PN) Sequence, dimana proses pengiriman dan penerimaan kode dilakukan dengan konsep Time Division Multiplexing Access (TDMA). Konsep tersebut dilakukan dengan memanfaatkan penggiliran waktu antara kode yang dikirim pada waktu pertama oleh pengirim pertama kepenerima pertama dan kedua serta kode yang dikirim pada waktu kedua. Data yang diterima seperti pada persamaan (1),

$y(t)=\left[y_{11} y_{12} y_{21} y_{22}\right]$

dengan,

$y(t) \quad$ : sinyal yang diterima dengan

$y_{11} \quad$ : data dari pemancar satu ke penerima satu

$y_{12}$ : data dari pemancar satu ke penerima kedua

$y_{21}$ : data dari pemancar dua ke penerima pertama

$y_{22}$ : data dari pemancar kedua ke penerima kedua.

Berdasarkan konsep TDMA, data yang diterima disimpan dalam TDMS (media penyimpanan pada front end Labview) sesuai pada tabel di bawah ini, urutan penyimpanan data tersebut ditunjukkan pada Tabel 2. 
Tabel 2. Urutan Penyimpanan Data Pengukuran

\begin{tabular}{|c|c|c|c|}
\hline Waktu Transmit & PosisiTx & Posisi Rx & Nama File \\
\hline \multirow{2}{*}{1} & \multirow{2}{*}{$\mathrm{A}$} & $\mathrm{A}$ & Y11.txt \\
\cline { 3 - 4 } & & $\mathrm{B}$ & Y21.txt \\
\hline \multirow{2}{*}{2} & \multirow{2}{*}{$\mathrm{B}$} & $\mathrm{A}$ & Y12.txt \\
\cline { 3 - 4 } & & $\mathrm{B}$ & Y22.txt \\
\hline
\end{tabular}

Posisi A dan B menunjukkan posisi dari antena pemancar dan penerima, setelah data yang diterima sesuai dengan penamaan nama file, langkah berikutnya melakukanpre-processing data untuk mendapatkan parameter kanal sebagai berikut,

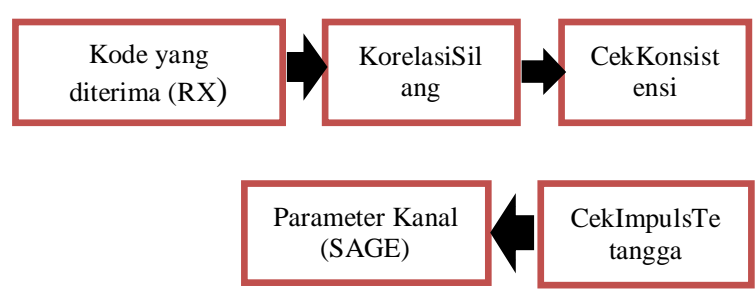

Gambar 5. Pre-Procesing Data Pengukuran

Berdasaran blok diagram pada Gambar 5, pengukuran parameter kanal didapatkan dari hasil korelasi silang antara kode yang dikirim dengan kode yang diterima yang disebut Respon Impuls dalam bentuk imajiner. Korelasi silang ditunjukkan pada persamaan (2). Korelasi silang merepresentasikan bentuk responimpuls, yang digunakan untuk menentukan karakteristik kanal. Namun pada makalah ini tidak membahas karakteristik kanal, melainkan membahas parameter fisik dari skenario kanal tertentu, yang didapatkan dari SAGE, sehingga makalah ini menampilkan respon impuls dari suatu kanal untuk mengetahui posisi sinyal yang asli. Data yang diolah selanjutnya bukan data hasil korelasi dari kode yang diterima, melainkan sinyal yang diterima di setiap pengiriman. Sinyal yang diterima ditunjukkan pada persamaan (2).

dengan,

$$
\rho_{y x}(\tau)=\sum_{t=-\infty}^{t=\infty} p n(t) \cdot p n(t-\tau) \cdot h(t-\tau)
$$

$$
\begin{array}{ll}
p n(t) & : \text { input sinyal berupa kode pn sequence } \\
p n(t-\tau) & : \text { sinyal input yang telahdigesersejauh }(\tau) \\
h(t-\tau) & : \text { respon impuls yang digeser sejauh }(\tau)
\end{array}
$$

Respon Impuls yang diolah sebanyak empat data dari kode yang diterima $\left(y_{11} y_{12} y_{21} y_{22}\right)$. Setiap Respon Impuls selanjutnya difilter guna menghilangkan noise dengan menggunakan metode Sousa meliputi proses threshold, cek konsistensi impuls, dan cek impuls tetangga. [1]. Output dari proses ini diperoleh nilai excess delay dari impuls-impuls maksimum (puncak). Nilai excess delay ini selanjutnya digunakan sebagai inputan bagi algoritma SAGE untuk mengestimasi parameter kanal lainnya seperti DoD, DoA, dan amplitude kompleks. [11]

\subsection{Space Alternating Generalized Expectation Maximisation}

SAGE merupakan salah satu metode yang digunakan untuk mendapatkan parameter kanal yaitu delay, DoA (Direction of Arrival), DoD (Direction of Departure) dan Amplitudo kompleks. SAGE merupakan salah satu metode yang akurat untuk memisahkan sinyal asli dengan sinyal pantulan, dimana SAGE dapat mendeteksi sinyal dengan baik pada kondisi kanal yang memungkinkan terjadi banyaknya pantulan atau dengan kata lain banyak penghalang. Hal 
ini telah dibuktikan oleh [5] yang menganalisa kinerja SAGE. Selain itu, SAGE dapat digunakan pada sebarang antenna, artinya dapat diterapkan pada bentuk geometri array antenna. Oleh sebab itulah penelitian ini menggunakan konsep antena array linier dengan jarak antara array antenna sebesar $\frac{\lambda}{2}$. Jarak ini mengurangi terjadinya mutual copling yang disebabkan oleh tegangan di satu antena akibat arus yang berdekatan. [12].

Data yang telah diolah dijadikan sebagai inputan pada SAGE, unuk mendapatkan parameter sudut. Kemudian data tersebut akan melalui proses Expectation Step (E-Step) dan Maximazation Step (M-Step). Proses E-Step pada persamaan (3). [5]

$x_{l}\left({\widehat{t ; \widehat{\boldsymbol{\theta}}^{\prime}}}_{l^{\prime}}\right)=y(t)-\sum_{\ell^{\prime}=1, \ell^{\prime} \neq \ell}^{L} s\left(t ; \widehat{\boldsymbol{\theta}}_{l^{\prime}}\right)$

dengan,

$y(t) \quad$ : sinyal yang diterima

$s\left(t ; \widehat{\boldsymbol{\theta}}^{\prime}{ }_{l^{\prime}}\right) \quad$ : komponen sinyal lintasan jamak ke $l^{\prime}$

$\widehat{\boldsymbol{\theta}}^{\prime}$ : himpunan parameter kanal

$\widehat{\boldsymbol{\theta}}^{\prime}:\left\{\widehat{\zeta_{2, l}}{ }^{\prime \prime}, \widehat{\zeta_{1, l}^{\prime \prime}}, \widehat{\tau_{l}^{\prime \prime}}\right\}$

Proses M-Step pada persamaan (3), dimana proses ini mendeteksi parameter DoA, DoD, dan delay.

\subsubsection{Persamaan Paramater DoA $\left(\widehat{\zeta_{2, l}{ }^{\prime \prime}}\right)$}

$\widehat{\zeta_{2, l}}{ }^{\prime \prime}=\underbrace{\arg \max }_{\zeta_{2, l}}\left\{z_{l}\left(\zeta_{2, l}, \widehat{\zeta_{1, l}}, \widehat{\tau_{l}^{\prime}} ; \hat{x}_{l}\left(k ; \widehat{\boldsymbol{\theta}}_{l}^{\prime}\right)\right)\right\}$

$z_{l}\left(\zeta_{2, l}\right)=\underbrace{\arg \max }_{\zeta_{2, l}}\left\{\sum_{m=1}^{M}\left|\sum_{k=1}^{K} \boldsymbol{c}_{2}\left(\Omega_{2, l}\right)^{H} \hat{x}_{l, m, k}\left(k ; \widehat{\boldsymbol{\theta}}_{l}^{\prime}\right)\right|\right\}$

dengan,

$\widehat{\zeta_{1, l}}, \quad$ : inisialisasi parameter DoD

$\widehat{\tau_{1, l}} \quad:$ inisialisasi parameter delay

$\hat{x}_{l}\left(t ; \widehat{\boldsymbol{\theta}}_{l}^{\prime}\right) \quad$ : output E-step (dimensi N x K)

$\boldsymbol{c}_{\mathbf{2}}\left(\Omega_{2}, l\right) \quad$ : steering vector $\mathrm{DOA}(\mathrm{N} \times 180 * 360)$

$\mathrm{M} \quad$ : jumlah antenna penerima

$\mathrm{K} \quad$ : sampel pengamatan

2.3.2 Persamaan Parameter DoD $\left(\widehat{\zeta_{1, l}{ }^{\prime \prime}}\right)$

$\widehat{\zeta_{1, l}{ }^{\prime \prime}}=\underbrace{\arg \max }_{\zeta_{1, l}}\left\{z_{l}\left(\zeta_{1, l}, \widehat{\zeta_{2, l}{ }^{\prime \prime}}, \widehat{\tau_{l}} ;{\widehat{x_{l}}}_{l}\left(k ; \widehat{\boldsymbol{\theta}}^{\prime}{ }_{l}\right)\right)\right\}$

$$
z_{l}\left(\zeta_{1, l}, \hat{\zeta}_{2, l}^{\prime \prime}, \hat{\tau}_{l}^{\prime} ; \hat{x}_{l}\left(k ; \widehat{\boldsymbol{\theta}}_{l}^{\prime}\right)\right)=\underbrace{\arg \max }_{\zeta_{1, l}}\left\{\sum_{n=1}^{N}\left|\sum_{k=1}^{K} \boldsymbol{c}_{\mathbf{2}}\left(\Omega_{2, l}\right)^{H} \hat{x}_{l, n, k}\left(k ; \widehat{\boldsymbol{\theta}}^{\prime}{ }_{l}\right) \boldsymbol{c}_{\mathbf{1}}^{*}\left(\Omega_{1}\right)\right|\right\}
$$

dengan,

$\boldsymbol{c}_{2}\left(\Omega_{2, l}\right)^{H}$ : Steering vector dari sudut DoA yang sudah terupdate $(\mathrm{N} \times 1)$, operator $\mathrm{H}$ menunjukkan transpose conjugate.

$\boldsymbol{c}_{\mathbf{1}}^{*}\left(\Omega_{1}\right)$ : Matriks steering vector $\mathrm{DoD}(\mathrm{M} \mathrm{x}(180 * 360))$, operator * menunjukkan conjugate. 


\subsubsection{Persamaan Deteksi Delay $\left(\widehat{\tau_{l}{ }^{\prime \prime}}\right)$}

$\widehat{\tau_{l}^{\prime \prime}}=\underbrace{\arg \max }_{\tau_{l}}\left\{z_{l}\left(\widehat{\zeta_{1, l}}{ }^{\prime \prime}, \widehat{\zeta_{2, l}{ }^{\prime \prime}}, \tau_{l} ; \widehat{x}_{l}\left(k ; \widehat{\boldsymbol{\theta}}_{l}^{\prime}\right)\right)\right\}$

$z_{l}\left(\tau_{l}, \hat{\zeta}_{2, l}^{\prime \prime}, \hat{\zeta}_{1, l}^{\prime \prime} ; \hat{x}_{l}\left(k ; \widehat{\boldsymbol{\theta}}^{\prime}{ }_{l}\right)\right)=\underbrace{\arg \max }_{\tau_{l}} \sum_{k=1}^{K}\left|\sum_{m, n=1}^{M, N} \boldsymbol{c}_{\mathbf{2}}\left(\Omega_{2, l}\right)^{H} \hat{x}_{l, m, n, k}\left(k ; \widehat{\boldsymbol{\theta}}^{\prime}{ }_{l}\right) \boldsymbol{c}_{\mathbf{1}}^{*}\left(\Omega_{1, l}\right) \boldsymbol{p} \boldsymbol{n}\left(\boldsymbol{k}-\boldsymbol{\tau}_{\boldsymbol{l}}\right)\right|$ dengan,

$\boldsymbol{c}_{\mathbf{1}}^{*}\left(\Omega_{1, l}\right) \quad:$ Steering vector dari sudut DoD yang sudah terupdate (M x 1),

$c_{2}\left(\Omega_{2, l}\right)^{H} \quad:$ Steering vector dari sudut DoA yang sudah terupdate ( $\left.\mathrm{N} \times 1\right)$

$\boldsymbol{p n}\left(\boldsymbol{t}-\boldsymbol{\tau}_{\boldsymbol{l}}\right) \quad$ : Deretan pn sekuen yang terdelay $\tau_{l}$

\section{HASIL DAN PEMBAHASAN}

Pengukuran ditunjukkan pada Gambar 6, dimana terdiri dari 2 pemancar dan 2 penerima yang terhubung dengan masing-masing komputer sebagai kontrol dalam menentukan panjang kode yang akan dikirim, sampling setiap chip, sampling setiap frame, dan IQ Rate. Parameter inputan tersebut terdapat pada Front End dari Labview yang sudah terpasang pada laptop pengirim dan laptop penerima, untuk pentransmisian kode.

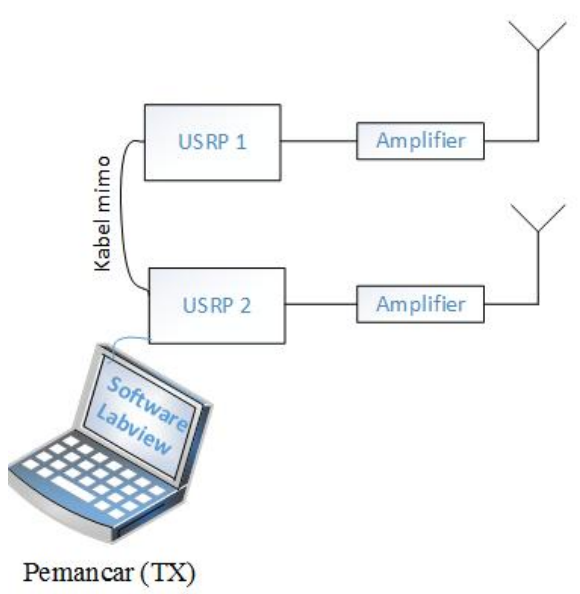

Gambar 6. Pengukuran TX dan RX

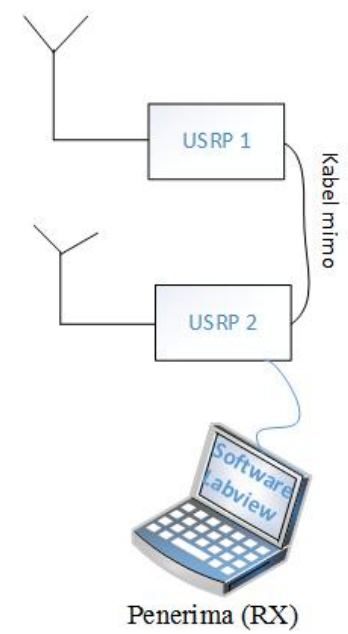

Penerima (RX)

Pengukuran kanal indoor dilakukan pada frekeunsi 2,4 GHz di ruang Hall Gedung Baru Politeknik Elektronika Surabaya terlihat pada Gambar 7, lokasi tersebut mendukung kondisi pengukuran, karena bentuk lokasi persegi panjang yang memudahkan pemakalah untuk melakukan validasi Ray Tracing, terdapat penghalang tembok beton mendukung terjadinya pantulan sinyal, dan beberapa tiang penyangga gedung. 


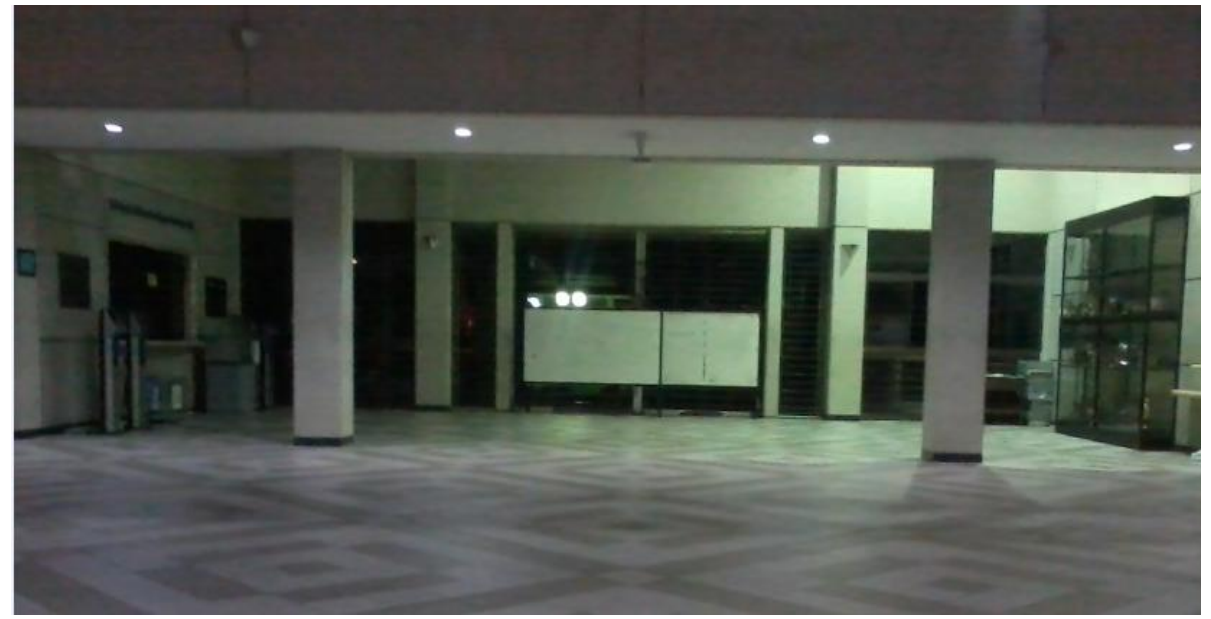

Gambar 7. Lokasi Pengukuran - Hall PENS

Instalasi perangkat terdiri dari 2 USRP beserta antena di bagian pemancar dan 2 USRP di bagian penerima, Kedua USRP tersebut dihubungkan oleh kabel MIMO, dan USRP dihubungkan dengan kabel Giga Ethernet. Instalasi pengukuran terlihat pada Gambar 8,

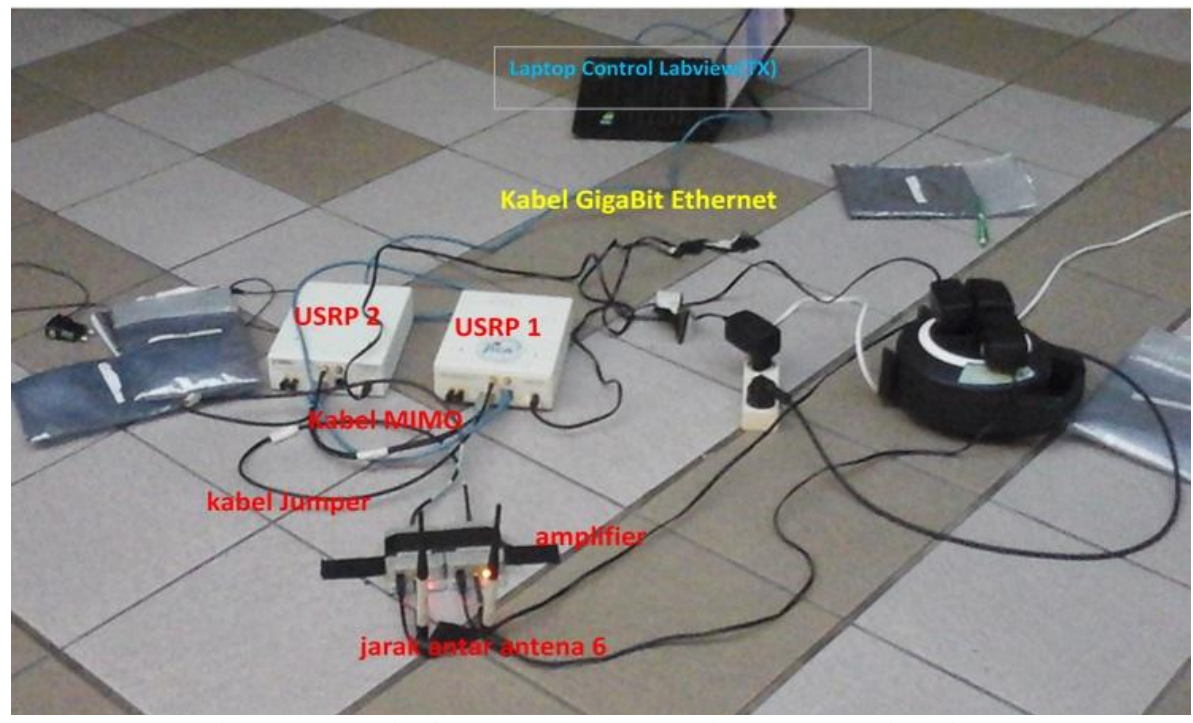

Gambar 8. Instalasi Perangkat Pengukuran Kanal Indoor

Pengukuran diawali dengan mengatur parameter input pada USRP, ditunjukkan pada Tabel 2. Pengecekan data yang diterima adalah dengan menampilkan respon impuls yang terlihat pada gambar 10, dari gambar tersebut, sinyal yang mempunyai nilai daya tertinggi diasumsikan nilai dari sinyal LOS (bukan sinyal multipath), dimana nilai tersebut digeser ke titik nol (excess delay) seperti pada gambar. Penggeseran tersebut dilakukan karena perangkat USRP pada TX dan RX selama pentransmisian tidak sinkron oleh sebab itulah pengukurannya menggunakan konsep TDMA. Hal ini berpengaruh terhadap pendeteksian parameter delay. Berikut respon impuls dari hasil pengukuran setelah dilakukan pengecekan konsistensi dengan metode Sousa. 
Tabel 3. Parameter Setup Pengukuran

\begin{tabular}{|l|l|}
\hline Frekuensi & $2450 \mathrm{MHz}$ \\
DayaTerima USRP & $0 \mathrm{dBm}:(-100 \mathrm{dBm})$ \\
Gain Transmit Amplifier & $17 \mathrm{~dB}$ \\
Sample width & $8 \mathrm{dit}$ \\
Gain internal USRP & $31.5 \mathrm{~dB}$ \\
DayaPancar USRP & $20 \mathrm{dBm}$ \\
\hline Orde PN & 8 \\
Jumlah Sample & 510 \\
\hline IQ Rate & $33 \mathrm{MHz}$ \\
Chiprate & $16,5 \mathrm{MS} / \mathrm{s}$ \\
Tc(periode chip) & $60 \mathrm{~ns}$ \\
Resolusi Temporal Sounder & $60 \mathrm{~ns}(\geq \mathrm{Tc})$ \\
PanjngResponMaksimal & $15300 \mathrm{~ns}$ \\
\hline Tinggi Antena & $20 \mathrm{~cm}$ \\
JenisAntena & Monopole Omnidirectional \\
Frekuensiantena & Vertical \\
\hline
\end{tabular}

USRP hanya bisa mendeteksi tiga sinyal sesuai dengan hasil kroskorelasi, hal ini dikarenakan resolusi temporal dari USRP 60 ns. Hasil Kroskorelasi digunakan untuk mendapatkan nilai parameter delay, dimana delay 0 ns hanya untuk sinyal LOS, delay $90 \mathrm{~ns}$ untuk sinyal multipath pertama, delay 240 ns untuk sinyal multipath kedua. Sedangkan untuk mendapatkan parameter DoA dan DoD, diproses dengan SAGE dengan menginputkan nilainilai delay tersebut.

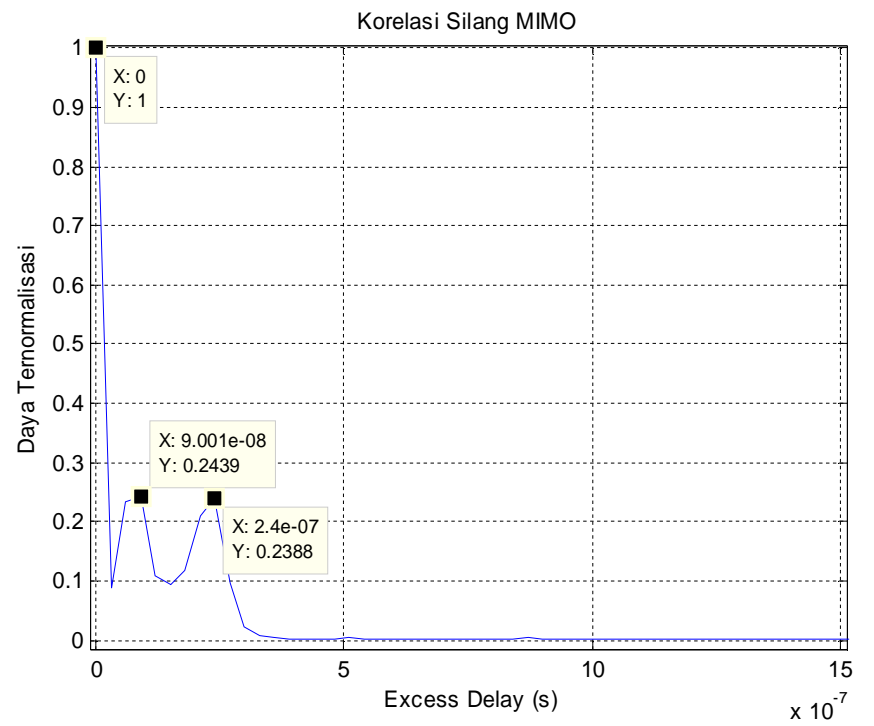

Gambar 9. Hasil Kroskorelasi Silang Data yang Diterima

Parameter DoA dan DoD yang didapatkan dari SAGE, disajikan pada tabel III dan IV, untuk menguji kebenarann parameter sudut (DoA dan DoD) yang didapat dari SAGE, maka perlu dilakukan validasi Ray Tracing, yang menggambarkan posisi antena penerima dan pemancar, ukuran ruangan, dan kemungkinan sinyal multipath yang terjadi. Ray Tracing lokasi pengukuran ditunjukkan pada Gambar 9. 


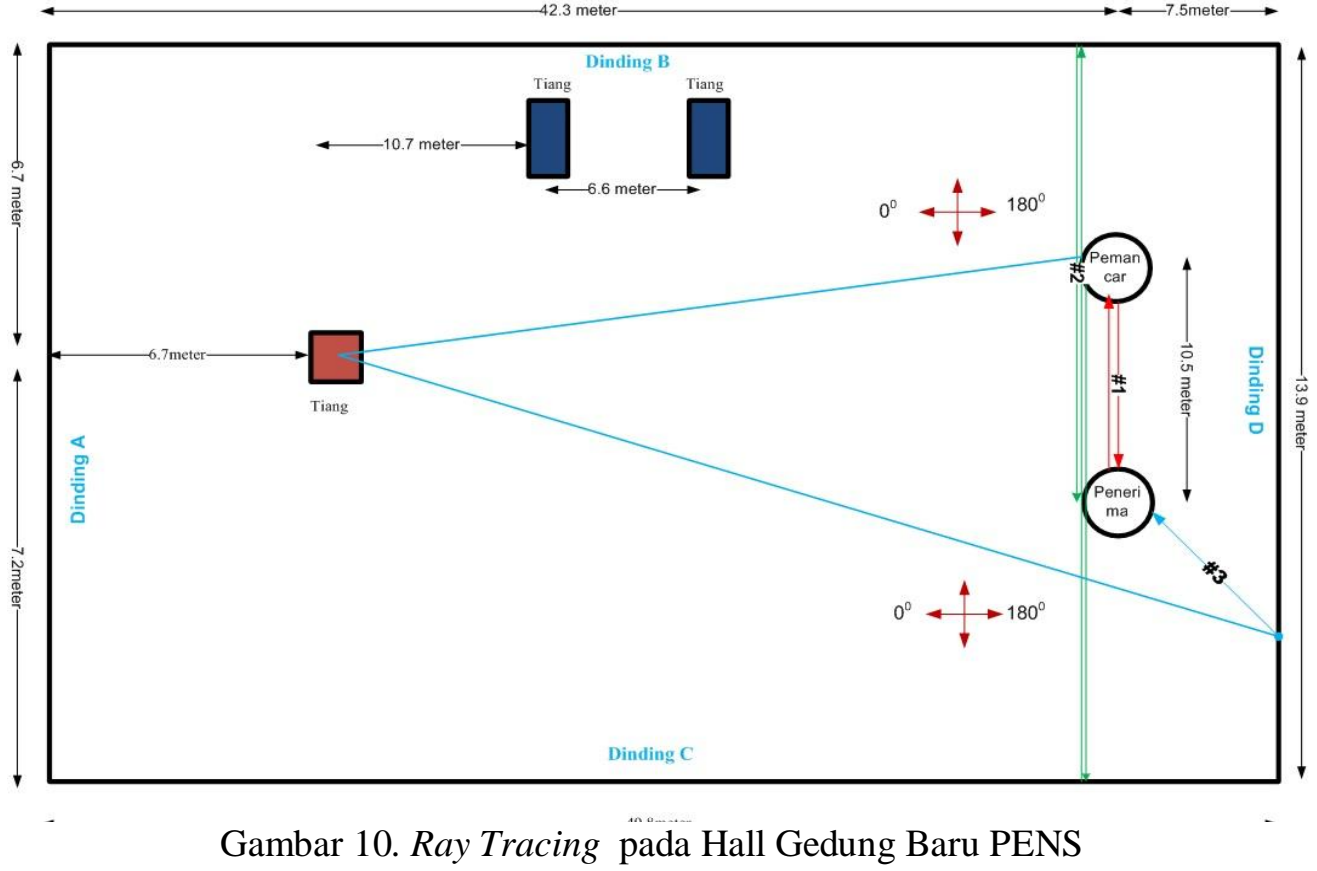

Berdasarkan hasil Ray Tarcing, terdapat tiga sinyal yang terdeteksi dari lintasan yaitu Sinyal LOS yang didapatkan dari pentransmisian langsung tanpa pantulan dimana jarak Pengirim dan Penerima terhitung 10.5 meter (pada Ray Tracing diberi keterangan lintasan \#1). Sinyal kedua didapatkan dari pantulan dari dinding $\mathrm{C}$ ke dinding $\mathrm{B}$ terhitung dengan jarak 38.3 meter (keterangan lintasan \#2). Sinyal ketiga merupakan hasil pantulan dari tiang ke dinding D terhitung dengan jarak 85.25 meter (keterangan \#3). Validasi Ray Tracing pada makalah ini hanya untuk parameter sudut, sedangkan delay dan amplitudo didapatkan dari hasil kroskorelasi sinyal yang dikirim dengan sinyal yang diterima. Hasil deteksi parameter sudut dengan SAGE dan Ray Tracing disajikan pada Tabel 3 dan Tabel 4 di bawah ini,

Perbandingan hasil deteksi parameter DoA dan DoD pada SAGE terhadap Ray Tracing, menunjukkan eror yang besar, hal ini dikarenakan resolusi dari perangkat USRP kurang mendukung, sehingga banyak sinyal multipath yang tidak terdeteksi, dikarenakan sinyal yang saling berdekatan tertumpuk, sehingga sulit SAGE untuk mendeteksi sinyal tersebut. Selain itu, terdapat sumber sinyal yang datang dari perangkat wifi yang lain, sehingga memungkinkan menganggu hasil pengukuran seperti hasil estimasi sudut DoD pada lintasan \#3. Faktor yang lainnya adalah pola radiasi antena linier atau human error selama pengukuran dilakukan, seperti kurang teliti dalam memposisikan jarak antar kedua antena.

Tabel 4. Deteksi Parameter DoA

\begin{tabular}{|c|c|c|c|}
\hline Lintasan (m) & $\begin{array}{c}\text { Hasil } \\
\left.\text { SAGE ( }{ }^{\mathbf{0}}\right)\end{array}$ & $\begin{array}{c}\text { Hasil Ray } \\
\text { Tracing }\left({ }^{\mathbf{(}}\right)\end{array}$ & $\begin{array}{c}\text { Eror } \\
\left({ }^{\%}\right)\end{array}$ \\
\hline $\begin{array}{c}\# 1(\text { LOS }) \\
10.5\end{array}$ & 125 & 90 & 28 \\
\hline $\begin{array}{c}\# 2(\mathrm{C}, \mathrm{B}) \\
38,3\end{array}$ & 119 & 90 & 24 \\
\hline $\begin{array}{c}\# 3 \text { (Tiang,D) } \\
85.25\end{array}$ & 127 & 173 & 36 \\
\hline \multicolumn{3}{|c|}{ Rata-rata Eror (\%) } & $29.3 \%$ \\
\hline
\end{tabular}


Tabel 5. Deteksi Parameter DoD

\begin{tabular}{|c|c|c|c|}
\hline Lintasan (m) & $\begin{array}{c}\text { Hasil } \\
\text { SAGE } \\
\left.\mathbf{(}^{\mathbf{9}}\right)\end{array}$ & $\begin{array}{c}\text { Hasil Ray } \\
\text { Tracing }\left(^{\mathbf{0}}\right)\end{array}$ & $\begin{array}{c}\text { Eror } \\
\left(^{\%}\right)\end{array}$ \\
\hline $\begin{array}{c}\text { \#1(LOS) } \\
10.5\end{array}$ & 99 & 90 & 9 \\
\hline $\begin{array}{c}\# 2(\mathrm{C}, \mathrm{B}) \\
38,3\end{array}$ & 109 & 90 & 17 \\
\hline $\begin{array}{c}\text { \#3 (Tiang,D) } \\
85.25\end{array}$ & 44 & 7.1 & 83 \\
\hline \multicolumn{2}{|c|}{ Rata-rata Eror (\%) } & $36.3 \%$ \\
\hline
\end{tabular}

Pada Lintasan \#1 dan \#2, hasil estimasi parameter DoD lebih baik dibandingkan dengan estimasi parameter DoA, hal ini dikarenakan sifat dari SAGE, dimana SAGE lebih baik dalam mendeteksi sudut sinyal berangkat dibandingkan sudut sinyal yang diterima [5].

\section{KESIMPULAN}

Tingkat akurasi implementasi SAGE dalam mendeteksi parameter sudut pada pengukuran kanal indoor menggunakan USRP masih rendah, yaitu 29.3\% untuk deteksi DoA dan 36.3\% untuk deteksi DoD, dikarenakan resolusi temporal dari perangkat tidak dapat mendeteksi sinyal multipath dengan baik, sehingga hal ini menyebabkan analisis kondisi suatu kanal indoor kurang dapat dilakukan dengan baik, namun hal ini dapat ditingkat dengan menambahkan metode pengiriman data yang lain dengan konsep MIMO.

\section{SARAN}

Penelitian ini menerapkan konsep TDMA untuk sinkronisasi antara TX dan RX, sehingga konsep Komunikasi Array MIMO belum maksimal, sehingga untuk penelitian selanjutnya perlu ditambahkan metode khusus berupa tambahan perangkat yang dapat mensinkronisasikan TX dan RX pada USRP, salah satunya GSPO.

\section{UCAPAN TERIMA KASIH}

Pemakalah mengucapkan terimakasih kepada pihak Politeknik Elektronika Negeri Surabaya (PENS), karena telah mengijinkan untuk melakukan pengukuran kanal indoor pada Hall Gedung Baru PENS.

\section{DAFTAR PUSTAKA}

[1] Handayani, P. 2013, Spatial-Temporal Double-Directional Indoor Radio Channel for Cooperative Multi-Antenna Communication Systems, Disertasi Doktor Program Studi Teknik Elektro.

[2] Handayani, P, Gamantyo, P. Yasdinul, H. 2010, Evaluasi Sistem Pengukuran Kanal Radio Dua Arah Dalam Gedung pada Pita 2,5 GHz Menggunakan Antena Larik 3 Dimensi, 
Jurnal Penelitian dan Pengembangan Telekomunikasi, Vol.15, Diakses Tanggal 1 Juni 2010.

[3] Fleury, H.B. 2002, "High Resolution Channel Parameter Estimation for MIMO Aplications Using The SAGE Algorithm", IEEE International Zurich Seminar on Broadband Communications.

[4] Bernard, Fleury. 1999, "Channel Parameter Estimation in Mobile Radio Environments Using The SAGE Algorithm", IEEE Journal On Selected Areas On Communication, Vol.17, pp.434-450, March 1999.

[5] Musayyanah, P. Handayani, G. Hendrantoro, P. Hari Mukti 2016, "Performance Analysis of The SAGE Algorithm: Changing The Update Procedure", Intelligent Technology and Its Applications (ISITIA), International Seminar, pp 237-242.

[6]Frendiana, Viving, 2014, Pengukuran Respon Impuls Kanal Radio MIMO $2 \times 2$ pada Frekuensi 2,4 GHz Menggunakan WARP (Wireless Open Access Research Platform), Tesis, ITS.

[7] Molisch, A, 2011, Wireless Communication Second Edition, Wiley IEEE, California, USA.

[8] Reed, J.H. 2002, “Software Radio: A Modern Approach to Radio Engineering”, Prentice Hall, New Jersey.

[9] USRP NI2922 Block Diagram. National Instruments, http://zone.ni.com/reference/enXX/help/373380B-01/usrphelp/2922_block_diagram.

Diakses Tanggal 01 Desember 2015.

[10] Anggraeni, M.E., 2015, Analisis Karakteristik Penghambur Lokasi di Sekitar Relay pada Kanal MIMO Multi-Hop, Tesis Institut Teknologi Sepuluh Nopember, Surabaya.

[11] Martianda Erste, P. Handayani, G. Hendrantoro, 2016, "Double Directional Outdoor MIMO Channel Measurement at 2,4 GHz using SDR", Intelligent Technology and Its Applications (ISITIA), International Seminar, pp 255-260.

[12] Kevin, Jones, Olivia Levy, 2017, Perancangan Antena MIMO $2 x 2$ Array Rectanguler Patch dengan U-Slot untuk Aplikasi 5 G, Jurnal Nasional Teknik Elektro dan Teknologi Informasi, Vol. 6, No.1. 